\title{
POLLUTION CONTROL LEGISLATION IN ALBERTA
}

\author{
PETER G. SCHMIDT*
}

\begin{abstract}
The author provides a brief outline of pollution control legislation in Alberta and its effect upon the oil and gas industry. The Department of the Environment discharges its obligation of "regulating"environmental matters through various sources of legislation which allow for a flexible regulatory scheme adaptable to changing government policy. Direct regulation of the industry is achieved by requiring compliance with the regulations prior to the issue of licenses and permits. Further, various "Guidelines" for pollution control are being established and incorporated into such permits and licences. The author also provides a list of similar legislation existing in British Columbia, Saskatchewan, and Alberta.
\end{abstract}

In Alberta it is the Department of the Environment's obligation to "regulate" environmental matters. That word itself is defined simply: "to put in condition to work properly". Other definitions are: "to control by rule, principle or system", or "to keep at some standard".

The Department is involved in regulating the environment through (a) legislation that is directly administered by the Department; (b) legislation that is "incidental" legislation; in other words, legislation in respect of which the Department plays a supporting administrative role; and (c) legislation that affects the functioning of the Department because its intent is similar to the Department's "direct" legislation or "triggers" the application of the Department's legislation, but is administered by another Department.

A list of the foregoing is as follows:

\section{LEGISLATION ADMINISTERED BY THE DEPARTMENT OF THE ENVIRONMENT}

1. Agricultural Chemicals Act, R.S.A. 1970, c. 4

2. Beverage Container Act, S.A. 1971, c. 10

3. Clean Air Act, S.A. 1971, c. 16

4. Clean Water Act, S.A. 1971, c. 17

5. Department of the Environment Act, S.A. 1971, c. 24

6. Groundwater Control Act, R.S.A. 1970, c. 162

7. Land Surface Conservation and Reclamation Act, S.A. 1970, c. 34

8. Litter Act, S.A. 1972 , c. 61

9. Surface Reclamation Act, R.S.A. 1970, c. 356

10. Water Resources Act, R.S.A. 1970, c. 388

- Solicitor, Department of the Environment, Government of Alberta. 


\section{LEGISLATION IN WHICH THE DEPARTMENT OF THE ENVIRONMENT OR THE MINISTER HAS A DIRECT FUNCTION}

1. Alberta Environmental Research Trust Act, S.A. 1971, c. 31

2. Drainage Districts Act, R.S.A. 1970, c. 115

3. Environment Conservation Act, R.S.A. 1970, c. 125

4. Hydro and Electric Energy Act, S.A. 1971, c. 49

5. Irrigation Act, R.S.A. 1970, c. 192

6. Oil and Gas Conservation Act, R.S.A. 1970, c. 267

7. Wilderness Areas Act, S.A. 1970, c. 114

\section{LEGISLATION ADMINISTERED BY OTHER DEPARTMENTS THAT AFFECTS THE DEPARTMENT OF THE ENVIRONMENT}

1. Alberta Heritage Act, 1973, S.A. 1973, c. 5

2. Mines and Minerals Act, R.S.A. 1970, c. 238

3. Pipe Line Act, R.S.A. 1970, c. 272

4. Public Health Act, R.S.A. 1970, c. 294

5. Public Lands Act, R.S.A. 1970, c. 297

The third list is by no means exhaustive.

The legislation providing for the primary methods and standards of pollution control in Alberta are The Clean Air Act, The Clean Water Act, and The Land Surface Conservation and Reclamation Act, which affect the oil and gas industry through the application of The Oil and Gas Conservation Act.

At this point it becomes necessary to return to what is meant by the concept of "regulation".

Although all of the statutes herebefore mentioned contain some basic "do's" and "don'ts" of pollution control, they are all designed to permit day-to-day application and enforcement of, hopefully, meaningful principles, rules and standards through the use of a flexible regulatory scheme that is established by the Lieutenant-Governor in Council, a Minister or an officer or agency of the Crown by delegated authority in accordance with the limitation prescribed in the statute.

The regulatory scheme in Alberta is based on government policy as it existsand changes from time to time. Presently ${ }^{1}$

in general ... it will be the government's policy to impose pollution source standards of such initial severity as to prevent the need for revision of the standards at frequent intervals.

In this, there is, and will be, an increasing need and requirement that industry and government work in harmony because the emphasis will increasingly be on control through source emission standards.

1 Excerpts from the address by the Honourable W. J. Yurko, Minister of the Environment, Alberta, to the Petroleum Society of the Canadian Institute of Mining and Metallurgy on January 10, 1973. 
The regulatory scheme, insofar as it relates to the exploration and production phases of the oil and gas industry in Alberta, consists mainly of:

Alta. Reg. 10/73 (1973)

Regulations Under The Alberta Clean Air Act

Alta. Reg. 34/73 (1973)

Regulations Under The Alberta Clean Air Act

Alta. Reg. 35/73 (1973)

Regulations Under The Alberta Clean Water Act

Alta. Reg. 36/73 (1973)

Regulations Under The Alberta Clean Water Act

Insofar as pollution prevention and reclamation of lands is concerned, the industry will be affected by

Alta. Reg. 125/74 (1974)

Regulations Under The Alberta Land Conservation Act, and other planned regulations that will designate specific types of surface disturbances as "regulated surface operations" under The Land Surface Conservation and Reclamation Act. Examples of specific surface disturbances are named in section 23(1) of the Act and include

(a) geophysical operations,

(b) the drilling, operation or abandonment of a well,

(c) the construction, operation or abandonment of a pipe line, battery, processing plant, or site for surface disposal of solid or liquid waste, and

(d) the opening up, operation or abandonment of an oil sands excavation.

Generally the application of the foregoing regulations is triggered by an application for an Approval for a conventional oil or gas scheme under section 38 of The Oil and Gas Conservation Act or an oil sands recovery scheme under section 43 of that Act.

Under those sections "the Minister of the Environment may give his approval" with respect to the application for the scheme "as it affects matters of the environment"; the sections authorize the Minister to impose conditions that the applicant must comply with unless "the Lieutenant Governor in Council directs the conditions are not to be imposed".

A relatively elaborate "referral" system has been established between the Energy Resources Conservation Board and the Department as well as among the various divisions within the Department, to review applications such as the foregoing. ${ }^{2}$

The Minister's Approval, if granted, is in the form of a Ministerial Order incorporating by reference, as conditions of the Approval, the necessary permits, licences or other approvals prescribed under The Clean Air Act, The Clean Water Act, The Water Resources Act, and, in the near future, The Land Surface Conservation and Reclamation Act. The permits or licences under The Clean Air Act and The Clean Water Act, among other matters, also require compliance with the applicable regulations under those Acts, including the prescribed standards.

2 E.R.C.B. Informational Letter No. Il-OG-72-20. 
The operation of the subject matter of the Approved Scheme, whether a gas processing plant or an oil sands plant, is then governed by the contents of the regulations and all other conditions contained in the permit and licence.

A co-operative committee consisting of members designated by the Department, the E.R.C.B. and the oil and gas industry developed "Guidelines" respecting "Gas Processing Plants, Sulphur Recovery and Sulphur Dioxide Emission Management Standards"s and Gas Processing Plants Waste Water Management Standards".*

Frequently excerpts from both Guidelines are incorporated as provisions of Clean Air and Clean Water licences.

Permits and licences under The Clean Air Act or The Clean Water Act are also issued in respect of pipe line compressor stations, tank farms or underground storage facilities and, of course, refineries; these are not coupled with Ministerial Approvals.

Other "Guidelines" have been developed between the Board, the oil and gas industry, and the Departments of the Environment and Lands and Forests, relating to pollution control; these apply to the "Taking of Incinerator Stack Surveys at Sour Gas Processing Plants"s and to the "Surface Disposal of Sump Fluids from Well Sites".

The former is used as a precedent for provisions of Clean Air Act licences while the latter will be incorporated, with appropriate semantic changes, into the regulations under the Land Surface Conservation and Reclamation Act designating the drilling, operating and abandonment of a well as a regulated surface operation.

In addition to the foregoing, the oil and gas industry, like any other Alberta resident, is subject to the provisions of the Litter Act, and in all phases of its operation, must comply with the standards of good public health prescribed by the Department of Health and Social Development under its legislation; it must also observe the anti-pollution by-laws of the various municipalities in which it is operating.

\section{POLLUTION CONTROL LEGISLATION \\ IN BRITISH COLUMBIA, SASKATCHEWAN AND MANITOBA}

Since public awareness and concern respecting pollution differs only in degree, not in principle in the three other Western Canadian Provinces, it is no surprise there also to find similar regulatory anti-pollution schemes as in Alberta. The extent of each scheme appears to be directly proportional to the extent of industrial development in those Provinces.

Attached to this paper, marked "Appendix", is a list of "primary" antipollution legislation affecting the oil and gas industry in those Provinces. The list is by no means exhaustive and it is recommended that any solicitor acting in or for the industry familiarize himself with all of the anti-pollution legislation of

${ }^{3}$ E.R.C.B. Informational Letter Il-OG-74-5.

4 E.R.C.B. Informational Letter Il-OG-73-32.

5 E.R.C.B. Informational Letter Il-OG-73-25.

${ }^{\circ}$ Soon to be published. 
all of the jurisdictions in which his employer or client company is carrying on business.

A good starting point for such familiarization process is the General Index to "Eco/Log", "Canadian Pollution Legislation" published by Corpus Publishers Services Limited, 6 Crescent Road, Toronto, Ontario.

\section{APPENDIX}

"Primary" pollution control legislation of British Columbia, Saskatchewan and Manitoba:

(a) British Columbia

Environmental and Land Use Act, S.B.C. 1971 , c. 17

Litter Act, S.B.C. 1970 , c. 22

Petroleum and Natural Gas Act, S.B.C. 1965, c. 33

Pollution Control Act, S.B.C. 1967, c. 34

(b) Saskatchewan

Air Pollution Control Act, R.S.S. 1965, c. 167

Department of the Environment Act, S.S. 1972, c. 31

Litter Control Act, S.S. 1971, c. 23

Oil and Gas Conservation Act, R.S.S. 1965, c. 360

Water Resources Management Act, S.S. 1972, c. 146

(c) Manitoba

Clean Environment Act, S.M. 1972, c. 76 